\title{
Never a White Flag: The Memoirs of Jock Barnes, Waterfront Leader
}

\author{
Reviewed by Tony Simpson
}

Never a White Flag: The Memoirs of Jock Barnes, Waterfront Leader. Edited by Tom Bramble. Victoria University Press, 1998.

If they give a prize for most fascinating book of the year this is a strong contender. The 'fifty one', with its potent mixture of strike and lock-out, of de-registration, use of armed forces, and frightening emergency regulations, is a key element in the mythologies of the industrial left in this country. As a contribution to that tale this book is unparalleled, even by comparison with Dick Scott's classic 151 Days. And yet it is also a curiosity. This has nothing to do with its absolutely partisan approach which is, indeed, a large measure of its strength and power. Obviously the events it describes are as fresh to Jock Barnes at ninety as they were when they happened nearly half a century ago. This is understandable and entirely excusable: to have been the personal focus of the malice of a government armed with the Public Safety Conservation Act would rather tend to leave an indelible impression on a bloke. But it is a curiosity, too, because the New Zealand Barnes describes is a completely foreign country-a place where the entire Cabinet could concern itself on an almost blow-by-blow basis with whether hatch covers were more safely raised by crane or by hand!

Barnes's memoir is also a salutary reminder that we once lived in a country which was as prone to McCarthyism as its progenitor. He quotes then National parliamentarian Dean Eyre (later to be notorious during the Vietnam War for his 'basinful of bombs on Hanoi' remark) as saying of the watersiders that the fifty one dispute was part of an international communist conspiracy and suggesting that the union leaders should be shot. None of them were communists and the dispute had nothing to do with such matters, as Maurice Shadbolt makes clear in One of Ben's. That didn't stop the hysterical rightwingers who thought otherwise from shouting it and using the red scare to bring down the unions. Barnes's memoir makes clear just how nasty the time was. 
But there is an important question behind the fifty one which still needs to be answered. Famous event that it was, what has it signified over the succeeding half-century for workers and their unions? The book itself does not directly provide an answer although it implies one. This implication is more bluntly addressed in an excellent introduction by Tom Bramble of the University of Queensland. Workers are primarily defeated by their own leaders. In the case of the fifty one, the National government would never have prevailed if the union movement had not been divided and a significant portion of its leadership had not lined up with the Holland government. Rather than reflect on the betrayal by Fintan Patrick Walsh, subsequent generations of union leaders have concluded that the union movement cannot ultimately prevail against a determined government. Bramble argues that such a conclusion is nonsense and the experience of the Public Service Association in the early eighties supports his reading.

According to the publisher, the first run of Barnes's memoir sold out in remarkably quick time; one hopes that it finds a ready audience among current union leadership and that publication of Jock Barnes's account of the events of fifty one (in conjunction with recent events across the Tasman) will encourage a more robust and courageous approach to defending the rights of workers in the future.

Originally published in Kōtare 1, no. 1 (1998), pp. 109-110. 